\title{
Rationale of Blood Purification in the Post-Resuscitation Syndrome following Out-of-Hospital Cardiac Arrest: A Narrative Review
}

\author{
Sebastien Redant David De Bels Patrick M. Honoré \\ Department of Intensive Care, Brugmann University Hospital, Université Libre de Bruxelles (ULB), Bruxelles, Belgium
}

\section{Keywords}

Cytokines · Post-resuscitation syndrome - Systemic

ischemia/reperfusion response $\cdot$ Cytokine storm

\begin{abstract}
Even today, little is known about the pathophysiology of the post-resuscitation syndrome. Our narrative review is one of the first summarizing all the knowledge about this phenomenon. We have focused our review upon the potential role of blood purification in attenuating the consequences of the post-resuscitation syndrome. Blood purification can decrease the cytokine storm particularly when using a CytoSorb absorber. Acrylonitrile 69-based oXiris membranes can remove endotoxin and high-mobility group box 1 protein. Blood purification techniques can quickly induce hypothermia. Blood purification can be used with veno-arterial extracorporeal membrane oxygenation to remove excess water. Further trials are needed to provide more concrete data about the use of blood purification in the post-resuscitation syndrome.

(c) 2021 S. Karger AG, Basel
\end{abstract}

\section{Introduction}

Post-resuscitation syndrome (PRS) is the term used to cover the complex sequelae of resuscitation after cardiac arrest of any cause. The PRS that occurs following cardiac arrest can be attributed to global ischemia that results in widespread injury to body systems, followed by additional lesions during and after reperfusion [1]. This syndrome is in addition to the underlying pathology that caused the cardiac arrest and any pre-existing comorbidities [1]. One must be aware that targeted treatment of certain organs can have harmful consequences on other organs [1]. The PRS consists of 4 key elements: (1) post-resuscitation brain injury, (2) post-resuscitation cardiac dysfunction, (3) systemic ischemia/reperfusion response, and (4) persistence of the precipitating pathology [1] (Fig. 1).

\section{Pathophysiology}

Post-Resuscitation Brain Injury

Brain damage is the leading cause of morbidity/mortality in patients in whom return of spontaneous circulation (ROSC) is achieved. At the time of discharge from

$\begin{aligned} & \text { karger@karger.com } \\ & \text { www.karger.com/bpu }\end{aligned}$
Karger ${ }^{\prime /}$

Sebastien Redant

Intensive Care Medicine

Hopital Universitaire Des Enfants, Ave. J.J. Crocq 15

BE-1020 Brussels (Belgium)

Sebastien.redant@huderf.be 
Fig. 1. The post-resuscitation syndrome.

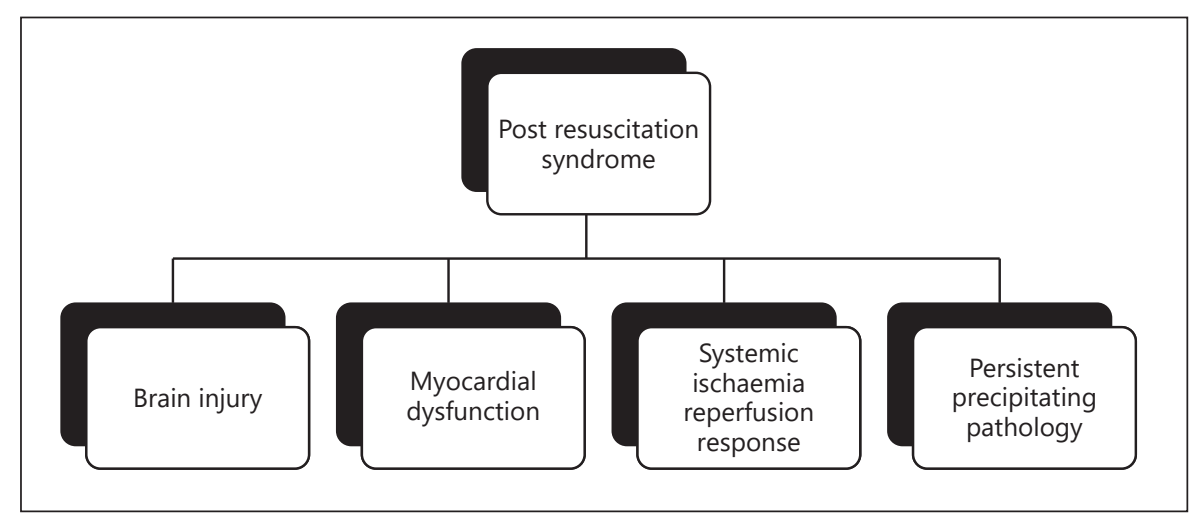

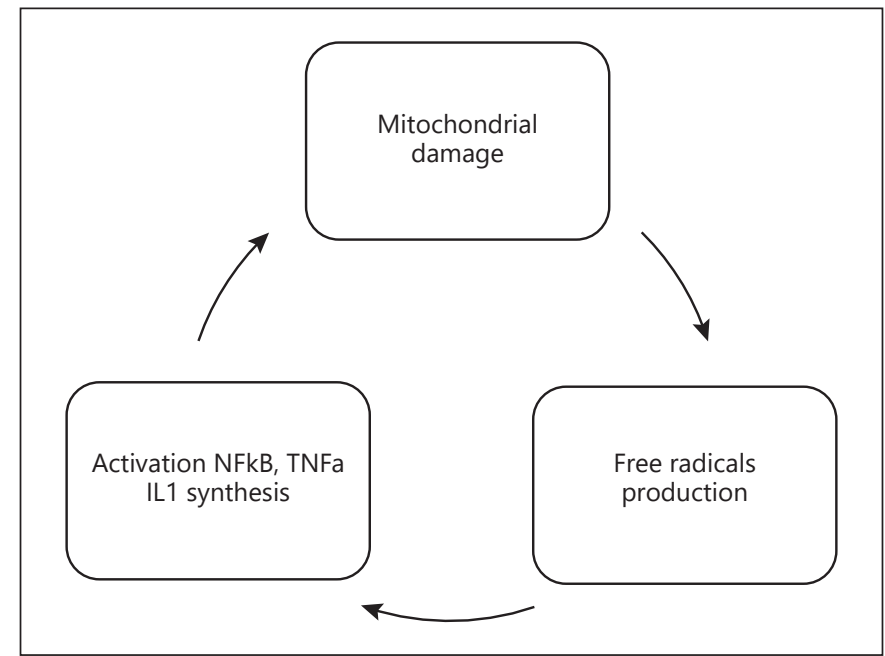

Fig. 2. Post-resuscitation brain damage (adapted from [2]). NF-kB, nuclear factor-kappa B, TNF- $\alpha$, tumor necrosis factor alpha; IL-1, interleukin-1.

the intensive care unit, brain damage is the cause of death in $68 \%$ of patients after out-of-hospital cardiac arrest and $23 \%$ of patients after intrahospital cardiac arrest [2]. The brain tissue is very sensitive to ischemia and reperfusion. Different mechanisms occur such as deregulation of calcium $\left(\mathrm{Ca}^{2+}\right)$ homeostasis, the production of free radicals, pathological protease cascade, and activation of cellular apoptosis [1]. Global ischemia is short lived and is characterized by a period of electron transport blockade. The lack of oxygen and glucose leads to significant changes in intracellular metabolism and ionic balance: decreased levels of adenosine triphosphate and $\mathrm{pH}$, increased levels of cyclic adenosine monophosphate, cytosolic $\mathrm{Ca}^{2+}$, and sodium $\left(\mathrm{Na}^{+}\right)$, depolarization of the cell membrane, and production of free radicals and glutamate [3]. Many of these phenomena can last for several days and slowly destroy the neural cells [1].

Blood Purification in the Post-

Resuscitation Syndrome

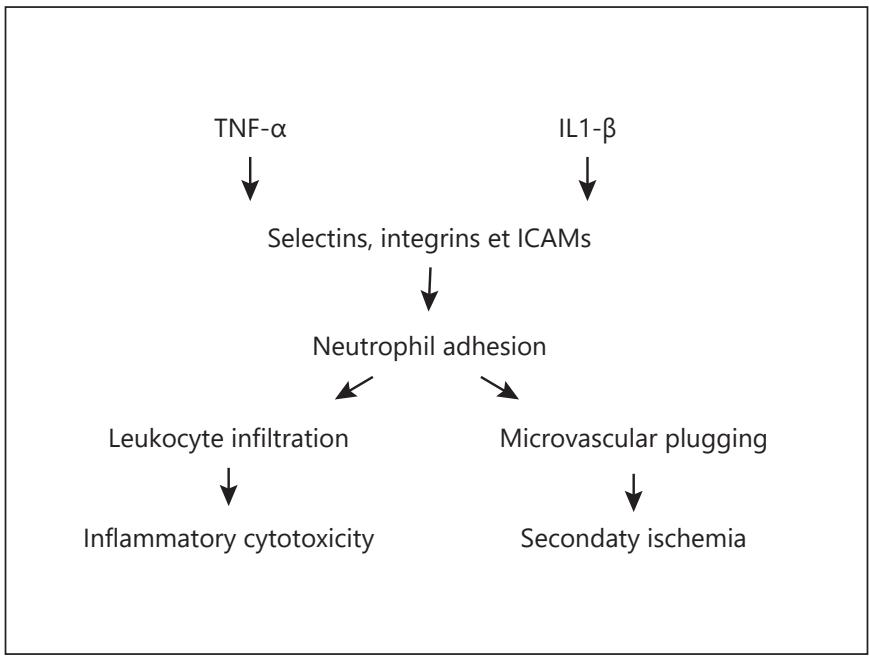

Fig. 3. Inflammatory cascade. IL- $1 \beta$, interleukin- $1 \beta$; TNF- $\alpha$, tumor necrosis factor- $\alpha$; ICAM, intercellular adhesion molecules.

Mitochondrial lesions are thought to generate free radicals that in turn activate nuclear factor-kappa $\mathrm{B}$ (NF$\kappa \mathrm{B})$, tumor necrosis factor alpha (TNF- $\alpha$ ), and interleukin-1 (IL-1) synthesis and the production of free radicals. $\mathrm{Ca}^{2+}$ and $\mathrm{Na}^{+}$augmentation subsequently occurs through long-term blocking of ionic channels (NMDA and other receptors) [3]. High levels of $\mathrm{Ca}^{2+}$ activate apoptotic pathways via various other signals including CD95 ligand and TNF- $\alpha$ (Fig. 2). The same phenomenon is observed in the inflammatory spectrum (Fig. 3). Early inflammation is deleterious to neuronal survival, while later inflammation may have a role in regeneration and recovery [4]. All of these mechanisms take time and are the result of a cascade of events that offer opportunities to intervene clinically with neuroprotective processes (e.g., hypothermia, hemofiltration, and hemoadsorption of mediators) [4-6] (Fig. 4). 


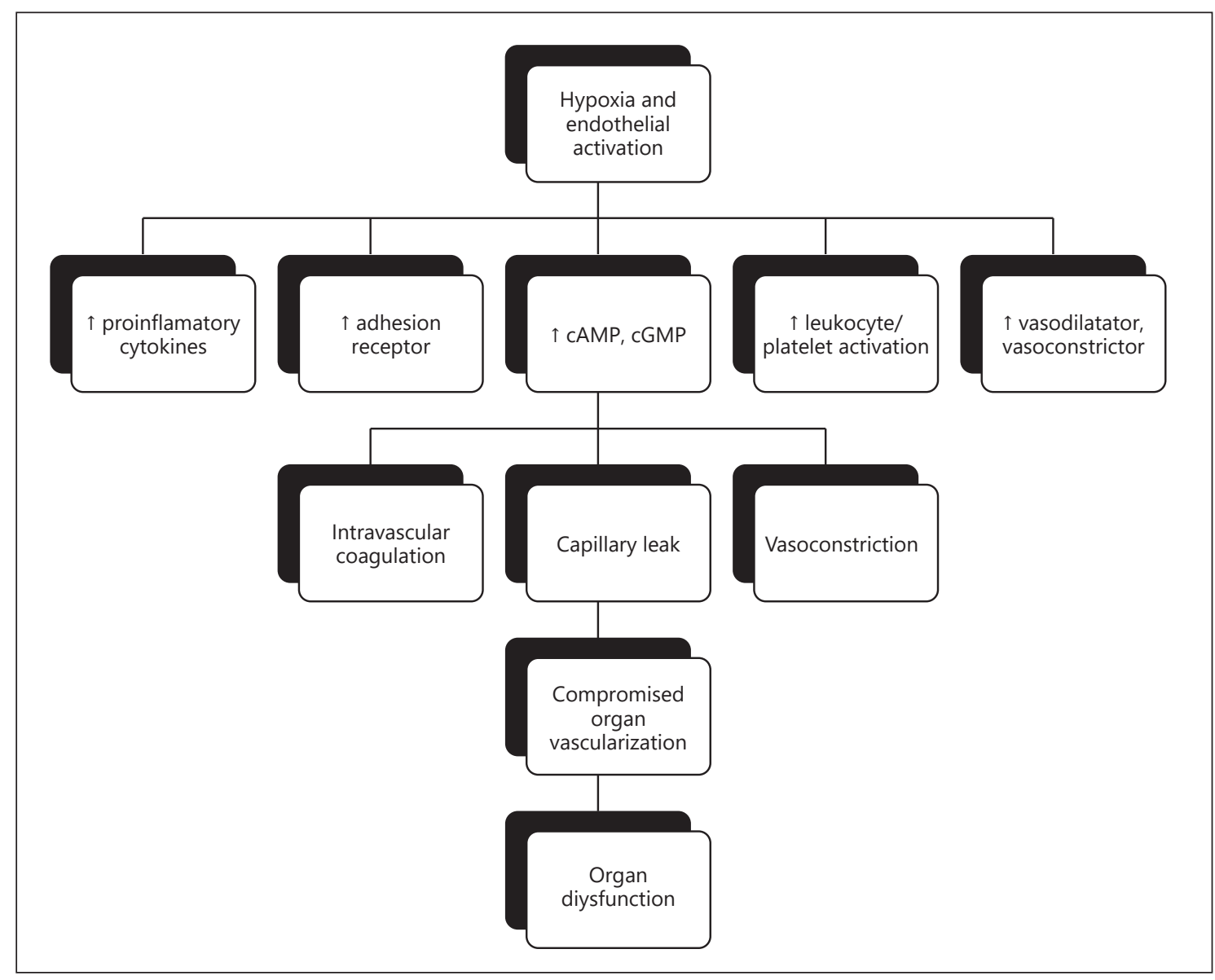

Fig. 4. Endothelial activation with vascular dysfunction leading to organ dysfunction. cAMP, cyclic adenosine monophosphate; cGMP, cyclic guanosine monophosphate.

\section{Post-Resuscitation Myocardial Dysfunction}

Immediately after resuscitation, the heart rate and blood pressure are extremely variable. Increased heart rate and normal or elevated blood pressure may be observed following the transient increase in circulating catecholamine concentrations. When post-cardiac arrest myocardial dysfunction occurs, it can be detected within minutes of ROSC by the use of appropriate monitoring [1]. In animal models of fibrillation-induced cardiac arrest, coronary flow is normal after resuscitation, but cardiac dysfunction occurs, characterized by low flow and high left-ventricular end-diastolic pressure, indicating a phenomenon of stunning rather than an ischemic injury [7]. In a study of 165 consecutive patients admitted after successful resuscitation following OHCA, a significant decrease in mean arterial pressure unresponsive to volume expansion was noted at $6.8 \mathrm{~h}$ after arrest [8]. Pulmonary artery catheter monitoring at $8 \mathrm{~h}$ after arrest demon- strated low cardiac index $\left(2.05 \mathrm{~L} / \mathrm{min} / \mathrm{m}^{2}\right.$ [range $1.43-$ 2.90]), which improved linearly with time [8]. Cardiac index change was accompanied by low filling pressures requiring up to 8 -L (7.5- to 9-L) filling volume, despite initiation of dobutamine or epinephrine [8]. Systemic hypotension was normalized within $72 \mathrm{~h}$ with an extremely positive fluid balance at day 3 in this study [8].

\section{Systemic Ischemia/Reperfusion Response}

During cardiac arrest, the supply of oxygen and metabolic substrates is abruptly interrupted. Cardiopulmonary resuscitation produces a decreased systemic oxygen delivery $\left(\mathrm{DO}_{2}\right)$. At the start of the decrease in cardiac output and $\mathrm{DO}_{2}$, oxygen consumption $\left(\mathrm{VO}_{2}\right)$ is maintained by an increase in oxygen extraction by the tissues $[9,10]$. This significant extraction causes the $\mathrm{ScvO}_{2}$ to drop to values below $20 \%$. The success of external cardiac compression immediately raises the $\mathrm{ScvO}_{2}$ above $40 \%$ [11, 
12]. Patients who regain ROSC tend to have higher partial pressure of venous oxygen, central venous oxygen saturation, and $\mathrm{pH}$ than no ROSC. The negative predictive value for ROSC with a maximum $\mathrm{ScvO}_{2}<30 \%$ has been reported to be 1.0. The positive predictive value for ROSC with a maximum $\mathrm{ScvO}_{2}>72 \%$ has been reported to be 1.0 [13]. Inadequate delivery of tissue oxygen may persist following ROSC due to persisting myocardial dysfunction, vasopressor-dependent hemodynamic instability, and microcirculatory failure [1].

Hypoxia also results in the production of IL-1, which is a multifunctional proinflammatory cytokine that induces the expression of adhesive molecules on endothelial cells and attracts and activates leukocytes [14]. IL-8 also attracts and activates neutrophils, promoting leukostasis in hypoxic organs. IL-6 appears to have an antiinflammatory potential in the setting of hypoxia $[14,15]$. IL-6 suppresses IL- 1 and TNF synthesis and induces the production of IL-1 and TNF antagonists, thereby dampening the inflammatory cascade $[14,15]$.

A significant number of cellular lesions appear during reperfusion. The main mechanism is the production of reactive oxygen intermediates including superoxide, single oxygen, hydroxyl radical, and hydrogen peroxide. The main source is xanthine oxidase activated by hypoxia [13]. In the absence of arginine, nitric oxide synthase, which is also an oxidoreductase, also produces oxygen in superoxide form [16]. These reactive oxygen intermediates accentuate the inflammatory reaction and increase the reperfusion-related organ damage.

\section{Persistent Precipitating Pathology}

In out-of-hospital cardiac arrest, half of the cases are found to be a result of acute coronary syndrome [1]. Coronary occlusion is found in $48 \%$ of cases [17]. Patients with ST-segment elevation myocardial infarction should undergo immediate coronary angiography $(+\mathrm{PCI}$ if indicated) [1]. However, a recent study has shown that in patients without ST-segment elevation myocardial infarction, immediate angiography (as compared to delayed angiography) did not convey a survival advantage [18]. Pulmonary embolism is the cause of $2-10 \%$ of cardiac arrests [1]. The post-cardiac arrest period must take into account the possibility of coexistence of cardiogenic shock with obstructive shock in combination with hypoxia. Hemorrhagic arrest occurs in the context of trauma and should be considered as separate entity. Hemorrhagic shock preceding cardiac arrest combines volume depletion, loss of red blood cells, and procoagulant factors with simultaneous activation of hemostasis and fi- brinolysis. The massive filling with crystalloids contributes to the appearance of a coagulopathy of consumption with hypothermia and progressive metabolic acidosis which will complicate post-cardiac arrest management [19]. Cardiac arrest of hypoxic origin, as occurs in chronic obstructive pulmonary disease or pneumonia, worsens prognosis due to severe respiratory insufficiency, the elevated risk of pulmonary edema, and the increase in the alveolo-capillary gradient [1]. Cerebral edema is also common in cardiac arrest of hypoxic origin. Hypoxia preceding the cardiac arrest leads to progressive cerebral lactic acidosis which in turn promotes cerebral edema [20]. The brain damage which conditions the patient's prognosis may be more marked under these conditions. Sepsis is an important cause of cardiac arrest [2]. Sepsis is also a frequent cause of acute respiratory distress syndrome and multiple organ failure that further complicates post-cardiac arrest management. The association of acute renal failure and cardiac decompensation is a common cause of death [21-23]. Other types, such as due to poisoning or hypothermia, require specific treatments $[1,24]$.

\section{Impact of Blood Purification in PRS}

Blood Purification to Decrease the Cytokine Storm?

The inflammatory response in patients with PRS is responsible for ischemia reperfusion lesions throughout the body, leading to a state of multiorgan failure and mortality. Brain damage is strongly correlated with significant synthesis of proinflammatory cytokines during cardiac arrest and resuscitation [25]. This condition has been described as a "sepsis-like syndrome" [26], and several studies have reported this "sepsis-like" cytokine profile [2730]. Unlike in sepsis, when cytokines are produced in response to microorganisms whose antigens remain in the body for a long time, driving a continuous inflammatory response, cytokine production following cardiac arrest reflects a nonspecific reaction to transient whole body ischemia [31]. Studies performed in vitro and in patients with brain death mainly related to cardiac arrest have shown that hemoadsorption therapies may have a potential role in attenuating the inflammatory response associated with brain death $[32,33]$. Plasma cytokine levels depend on several factors such as the intensity of production, the number of cell receptors available, the clearance of cytokines, and the affinity of the receptors for such mediators. For example, a low level of IL- 6 with a high level of receptor availability may induce a greater response than a high level of IL- 6 with low availability of receptors $[34,35]$. 
Among the proinflammatory cytokines that have been studied with procalcitonin (PCT), interleukin- $1 \beta$ has been found to be a particularly potent stimulant for calcitonin-mRNA expression and PCT synthesis [36]. PCT may be considered an indicator of the cytokine storm [37]. Decreased PCT concentration has been associated with improved clinical parameters such as lower vasopressor need and improved oxygenation [37].

A randomized controlled pilot study of conventional versus high cutoff hemofiltration in 30 septic patients (20 high cutoff vs. 10 control) showed a benefit of high cutoff hemofiltration in terms of norepinephrine requirement [38]. High cutoff membranes were also shown to remove more IL-6 and IL-1 than conventional membranes [38]. The HYPERDIA study, a single-center randomized pilot study, demonstrated that the addition of high cutoff veno-venous hemodialysis (HCO-CVVHD), with the aim of removing inflammatory mediators, did not bring benefits in post-cardiac arrest patients [39]. They compared 17 patients on HCO-CVVHD to 18 control patients and found no difference in catecholamine withdrawal time or 7-day mortality. Similarly, the inotropic score, mean arterial pressure, and cumulative fluid balance did not differ between groups. The premature termination of the study due to financial reasons resulted in the study being underpowered [39]. A randomized study of 61 patients admitted to the intensive care unit following OHCA has examined the effect of isovolumic high-volume hemofiltration (HF, $200 \mathrm{~mL} / \mathrm{kg} / \mathrm{h}$ for $8 \mathrm{~h}$ ) alone or in combination with hypothermia ( $\mathrm{HT}, 32^{\circ} \mathrm{C}$ for $24 \mathrm{~h}$ ) as compared to a control group [40]. The aim of the study was to act on the global inflammation that often occurs following cardiac arrest. HF was found to be associated with better 6-month survival $-45 \%$ in the HF group compared with $32 \%$ in the $\mathrm{HF}+\mathrm{HT}$ group and $21 \%$ in the control group - however, HF did not have a significant effect on IL-6, C3a, and terminal complement complex levels [40]. There are several hypotheses for the improvement in outcomes after HF without coincident significant changes in cytokine levels. One, the "peak concentration hypothesis" is the concept that HF decreases the peak serum levels of soluble mediators [41]. Another possible hypothesis is that other mediators may be involved in the phenomenon [40]. The effect of HF on serum concentrations of several inflammatory mediators, including TNF-alpha and 6-ketoprostaglandin $\mathrm{F} 1 \alpha$, has been investigated in anesthetized dogs on continuous veno-venous hemofiltration $(\mathrm{CVVH})$ at a filtration rate of $80 \mathrm{~mL} / \mathrm{kg} / \mathrm{h}$ [42]. The major hemodynamic finding was that endotoxin-induced hypotension was significantly attenuated by intensive CVVH.
ET-1 levels, but not LPS, TNF-alpha, or 6-keto-prostaglandin F1 $\alpha$, were lower during CVVH. TNF-alpha and endotoxin were not found in the ultrafiltrate. ET-1 is now considered a new proinflammatory cytokine [42].

A novel technique currently being studied is the use of the Cytosorb ${ }^{\circledR}$ (CytoSorbents Corporation, NJ, USA) device, a single-use hemoadsorption cartridge that works with a standard CVVH pump [43,44]. The cartridge is filled with porous polymer sorbent beads that provide an absorbent surface of approximately $45,000 \mathrm{~m}^{2}$ with a 60 $\mathrm{kDa}$ cutoff that removes the cytokines from the blood [45]. Use of the CytoSorb device has been shown to result in a $4-30 \%$ reduction in the level of cytokines compared to baseline and was not significantly different from 1 to $4 \mathrm{~h}$ [32]. Overall removal was greatest for IL-6 (28\%) and least for TNF (8.5\%) [32]. There is a need for larger randomized studies to evaluate the precise effect on mortality from this device (Cytosorb or HCO-CVVHD) [44, 46].

\section{Blood Purification to Remove Endotoxin?}

The median endotoxin value in a healthy subject is $<2$ $\mu \mathrm{g} / \mathrm{mL}$ [47]. For patients with sepsis, the median endotoxin level was found to be $300 \mu \mathrm{g} / \mathrm{mL}(110-726 \mu \mathrm{g})$ [47]. The host response depends on the physicochemical characteristics of the endotoxins, the relative concentration of endotoxin-binding protein, and the degree of response of the host to the endotoxin. The main plasma protein carrying endotoxins is lipopolysaccharide-binding protein (LBP). LBP is synthesized by the liver, binds endotoxin, and thus activates the cells carrying CD14 [48]. These LBPs are also responsible for the transfer of endotoxin with high-density lipoprotein which neutralizes the activity of endotoxin [47]. A "sepsis-like" syndrome has been demonstrated to occur in patients after cardiac arrest, with the presence of plasma endotoxin in $\sim 50 \%$ of patients and dysregulation of cytokine production [26].

Hemoperfusion can remove xenobiotics that are normally bound to plasma proteins [24]. The development of the 3-layer oXiris filter has allowed the selective adsorption of endotoxins [49-51]. When the oXiris filter is compared with a standard acrylonitrile 69-surface-treated (AN69ST) membrane, the difference is that in addition to the baseline AN69ST membrane there is a second layer of polyethylene at a concentration that is 10 times higher (and thus capable of adsorbing endotoxins) and a third heparin layer 10 times more concentrated than the $\mathrm{AN}$ 69ST membrane $\left(1,000 \mathrm{IU} / \mathrm{m}^{2}\right)$ [52]. The surface is coated with a polycationic polymer which is positively charged and adsorbs negatively charged endotoxins [52]. Studies 
of the device in animals have had encouraging results [52]. In a study of 16 patients with septic shock-associated acute renal failure, the use of the oXiris filter resulted in a decrease in the levels of endotoxin, TNF- $\alpha$, IL-6, IL-8, and IFN $\gamma$, when compared to a control group treated with a standard filter [53]. Its application in the care of patients after cardiac arrest should be the subject of future studies.

Blood Purification to Induce Hypothermia?

A randomized controlled trial of 400 patients following OHCA has studied outcomes of targeted temperature management using a femoral endovascular cooling device as compared to external cooling [54]. The endovascular technique resulted in better induction and control of hypothermia, but no significant difference was found in terms of survival with favorable neurological outcome [54]. A recent meta-analysis has shown a benefit of endovascular catheter devices when compared to air- or watercirculating blankets [5]. Invasive methods showed a lower probability of mortality than noninvasive methods (OR 0.84 [95\% CI: 0.74-0.94]; $p=0.002$ ) [5].

If a warming device is not applied, the circulation of the blood in a CVVH circuit has the potential side effect of cooling the patient, which can be beneficial after cardiac arrest. In an animal model, rapid hypothermia provided renal protection demonstrated by better clearance and a preserved morphology compared to the control population [55].

Improving post-resuscitation kidney protection after stopping post-resuscitation support could potentially increase the availability of kidneys for organ donation [55]. Studies are necessary to evaluate the use of CVVH for the cooling after cardiac arrest.

Blood Purification to Remove HMGB1?

High-mobility group box 1 protein (HMGB1), so called for its rapid migration on electrophoretic gels [56], is a protein secreted passively by necrotic cells, damaged cells, and by elements of the immune system. HMGB1 activates the production of inflammatory cells such as macrophages, dendritic cells, and monocytes [57]. In an animal model of myocardial ischemia/reperfusion injury, strong expression of HMGB1 was demonstrated on infiltrating leukocytes when compared to control subjects [57]. HMGB1 also plays an important role in the expression of proinflammatory cytokines [58]. It has been shown that an elevation of HMGB1 in the cerebrospinal fluid after ROSC is a risk factor for poor neurological prognosis $[59,60]$. The molecular weight of HMGB1 and neuron-specific enolase (NSE) is approximately 30,000 and 80,000 Da, respectively [59]. The phenomenon of ischemia/reperfusion at the cerebral level increases the permeability of the blood-brain barrier leading to leakage of NSE and HMGB1 into the blood. HMGB1 in the blood is responsible for systemic inflammation that plays an important role in the occurrence of multiorgan failure, the severity of which can be estimated by the Sepsis-related Organ Failure Assessment (SOFA) score. It has been shown that the elevation of HMGB1 during the first $24 \mathrm{~h}$ is correlated with NSE, IL-6, and SOFA score [60].

In a monocompartmental in vitro model containing 100 $\mu \mathrm{g}$ of HMGB1 and $35 \mathrm{~g}$ of bovine albumin, it was shown that hemofiltration using the AN69ST filter had the highest adsorption capacity for HMGB1 (100 $\mu \mathrm{g}$ during the first hour) and resulted in significant decreases in HMGB1 levels [61]. Polymethylmethacrylate has half the adsorption capacity of AN69ST. Polysulfone membranes and tubing have a much lower adsorption capacity [61]. The addition of highly adsorbent filters in conventional CVVHs used in immediate cardiac arrest can theoretically decrease HMGB1 and thereby decrease HMGB1-mediated ischemia/immediate reperfusion injury [62]. Further studies are needed to evaluate the impact of the use of blood purification to remove HMGB1 on clinically relevant outcomes.

Blood Purification Together with Emergency ECPR?

A study of 115 patients treated with veno-arterial extracorporeal membrane oxygenation (VA-ECMO) for refractory heart failure showed that a positive fluid balance from day 3 is associated with increased mortality. The odds ratio for 90-day mortality was found to be 4.02 (1.49-10.82) [63]. Controversy exists over whether adding CVVH into an ECMO circuit can influence mortality. A recent study did not find any impact of CVVH on mortality in patients with VA-ECMO when confounding factors were eliminated [64]. The use of early CVVH to prevent or correct fluid overload may result in better patient outcomes [64]. However, this has yet to be confirmed, and further studies are needed to measure the impact of CVVH combined with VA-ECMO on patient outcomes, including in patients with PRS.

\section{Conclusion}

Blood purification may have a potential role in attenuating the consequences of PRS. Blood purification can decrease the cytokine storm particularly when using a CytoSorb adsorber. AN69 oXiris membranes can remove endotoxin and HMGB1. Blood purification has the po- 
tential to induce hypothermia. Blood purification can be used with veno-arterial extracorporeal membrane oxygenation to remove excess water. Further trials are needed to clarify the utility of blood purification in PRS.

\section{Acknowledgements}

The authors would like to thank Dr. Melissa Jackson for reviewing the English language of the text.

\section{Statement of Ethics}

The authors have no ethical conflicts to disclose.

\section{Conflict of Interest Statement}

The authors declare to have no conflicts of interest.

\section{Funding Sources}

The authors did not receive any funding.

\section{Author Contributions}

R.S. and P.M.H. designed the paper. All authors participated in drafting and reviewing. All authors read and approved the final version of the manuscript.

\section{References}

1 Neumar RW, Nolan JP, Adrie C, Aibiki M, Berg RA, Böttiger BW, et al. Post-cardiac arrest syndrome. Circulation. 2008 Dec 2; 118(23):2452-83.

2 Laver S, Farrow C, Turner D, Nolan J. Mode of death after admission to an intensive care unit following cardiac arrest. Intensive Care Med. 2004 Nov;30(11):2126-8.

3 Lipton P. Ischemic cell death in brain neurons. Physiol Rev. 1999 Oct;79(4):1431-568.

4 Neumar RW. Molecular mechanisms of ischemic neuronal injury. Ann Emerg Med. 2000 Nov;36(5):483-506.

5 Calabró L, Bougouin W, Cariou A, De Fazio C, Skrifvars M, Soreide E, et al. Effect of different methods of cooling for targeted temperature management on outcome after cardiac arrest: a systematic review and metaanalysis. Crit Care. 2019;23(1):285.

6 Lother A, Benk C, Staudacher DL, Supady A, Bode $\mathrm{C}$, Wengenmayer $\mathrm{T}$, et al. Cytokine adsorption in critically ill patients requiring ECMO support. Front Cardiovasc Med. 2019; $6: 71$

7 Cerchiari EL, Safar P, Klein E, Cantadore R, Pinsky M. Cardiovascular function and neurologic outcome after cardiac arrest in dogs. The cardiovascular post-resuscitation syndrome. Resuscitation. 1993 Feb;25(1):9-33.

8 Laurent I, Monchi M, Chiche JD, Joly LM, Spaulding C, Bourgeois B, et al. Reversible myocardial dysfunction in survivors of outof-hospital cardiac arrest. J Am Coll Cardiol. 2002 Dec 18;40(12):2110-6.

9 Vincent JL. DO2/VO2 relationships. In: Pinsky MR, Payen D, editors. Functional hemodynamic monitoring. Heidelberg: Springer 2005. p. 251-8

10 Hall JB. Mixed venous oxygen saturation (SvO2). In: Pinsky MR, Payen D, editors. Functional hemodynamic monitoring. Heidelberg: Springer; 2006. p. 233-40.

11 Reinhart K, Bloos F. Central venous oxygen saturation (ScrO2). In: Pinsky MR, Payen D, editors. Functional hemodynamic monitor ing. Heidelberg: Springer; 2006. p. 241-50.

12 Nakazawa K, Hikawa Y, Saitoh Y, Tanaka N, Yasuda K, Amaha K. Usefulness of central venous oxygen saturation monitoring during cardiopulmonary resuscitation. A comparative case study with end-tidal carbon dioxide monitoring. Intensive Care Med. 1994;20(6):450-1.

13 Rivers EP, Martin GB, Smithline H, Rady MY, Schultz CH, Goetting MG, et al. The clinical implications of continuous central venous oxygen saturation during human CPR. Ann Emerg Med. 1992 Sep;21(9):1094-101.

14 Karimova A, Pinsky DJ. The endothelial response to oxygen deprivation: biology and clinical implications. Intensive Care Med. 2001 Jan;27(1):19-31.

15 Tilg H, Trehu E, Atkins MB, Dinarello CA, Mier JW. Interleukin-6 (IL-6) as an anti-inflammatory cytokine: induction of circulating IL-1 receptor antagonist and soluble tumor necrosis factor receptor p55. Blood. 1994; 83(1):113-8.

16 Huk I, Nanobashvili J, Neumayer C, Punz A, Mueller M, Afkhampour K, et al. L-arginine treatment alters the kinetics of nitric oxide and superoxide release and reduces ischemia/ reperfusion injury in skeletal muscle. Circulation. 1997 Jul 15;96(2):667-75.

17 Spaulding CM, Joly LM, Rosenberg A, Monchi M, Weber SN, Dhainaut JF, et al. Immediate coronary angiography in survivors of outof-hospital cardiac arrest. N Engl J Med. 1997; 336(23):1629-33.

18 Lemkes JS, Janssens GN, van der Hoeven NW, Jewbali LSD, Dubois EA, Meuwissen M, et al. Coronary angiography after cardiac arrest without ST-segment elevation. N Engl J Med. 2019;380(15):1397-407.

19 Cannon JW. Hemorrhagic shock. N Engl J Med. 2018;378(4):370-9.

20 Morimoto Y, Kemmotsu O, Kitami K, Matsubara I, Tedo I. Acute brain swelling after out-of-hospital cardiac arrest: pathogenesis and outcome. Crit Care Med. 1993;21(1): 104-10.

21 Husain-Syed F, Rosner MH, Ronco C. Distant organ dysfunction in acute kidney injury. Acta Physiol. 2020 Feb;228(2):e13357.

22 Ronco C, Navalesi P, Vincent JL. Coronavirus epidemic: preparing for extracorporeal organ support in intensive care. Lancet Respir Med. 2020 Mar;8(3):240-1.

23 Bellomo R, Kellum JA, Ronco C. Acute kidney injury. Lancet. 2012 Aug 25;380(9843): 756-66.

24 Ferrari F, Carletti A, Peroni N, Mongodi S, Esposito $\mathrm{P}$, Orlando A, et al. Brief report: a case of tramadol overdose: extracorporeal life support and hemoperfusion as life-saving treatment. Blood Purif. 2020 Feb 4;49(4):509-121.

25 Xiang Y, Zhao H, Wang J, Zhang L, Liu A, Chen Y. Inflammatory mechanisms involved in brain injury following cardiac arrest and cardiopulmonary resuscitation. Biomed Rep. 2016;5(1):11-7.

26 Adrie C, Adib-Conquy M, Laurent I, Monchi M, Vinsonneau C, Fitting C, et al. Successful cardiopulmonary resuscitation after cardiac arrest as a "sepsis-like" syndrome. Circulation. 2002 Jul 30;106(5):562-8.

27 Pinsky MR, Vincent JL, Deviere J, Alegre M, Kahn RJ, Dupont E. Serum cytokine levels in human septic shock. Relation to multiple-system organ failure and mortality. Chest. 1993 Feb;103(2):565-75

28 Taniguchi T, Koido Y, Aiboshi J, Yamashita T, Suzaki S, Kurokawa A. Change in the ratio of interleukin- 6 to interleukin-10 predicts a poor outcome in patients with systemic inflammatory response syndrome. Crit Care Med. 1999 Jul;27(7):1262-4.

29 Lekkou A, Karakantza M, Mouzaki A, Kalfarentzos F, Gogos CA. Cytokine production and monocyte HLA-DR expression as predictors of outcome for patients with community-acquired severe infections. Clin Diagn Lab Immunol. 2004 Jan;11(1):161-7. 
30 Kinasewitz GT, Yan SB, Basson B, Comp P, Russell JA, Cariou A, et al. Universal changes in biomarkers of coagulation and inflammation occur in patients with severe sepsis, regardless of causative micro-organism [ISRCTN74215569]. Crit Care. 2004 Apr;8(2): R82-90.

31 Pekkarinen PT, Skrifvars MB, Varon J. Can we treat post cardiac arrest shock by removing cytokines from circulation with high cut-off veno-venous hemodialysis? Resuscitation. 2019;140:203-4.

32 Kellum JA, Venkataraman R, Powner D, Elder M, Hergenroeder G, Carter M. Feasibility study of cytokine removal by hemoadsorption in brain-dead humans. Crit Care Med. 2008 Jan;36(1):268-72.

33 Venkataraman R, Song M, Lynas R, Kellum JA. Hemoadsorption to improve organ recovery from brain-dead organ donors: a novel therapy for a novel indication? Blood Purif. 2004;22(1):143-9.

34 Honore PM, Hoste E, Molnár Z, Jacobs R, Joannes-Boyau O, Malbrain MLNG, et al. Cytokine removal in human septic shock: where are we and where are we going? Ann Intensive Care. 2019 May 14;9(1):56.

35 van der Poll T, van de Veerdonk FL, Scicluna BP, Netea MG. The immunopathology of sepsis and potential therapeutic targets. Nat Rev Immunol. 2017 Jul;17(7):407-20.

36 Riedel S. Procalcitonin and the role of biomarkers in the diagnosis and management of sepsis. Diagn Microbiol Infect Dis. 2012 73(3):221-7.

37 Hawchar F, László I, Öveges N, Trásy D, Ondrik Z, Molnar Z, et al. Extracorporeal cytokine adsorption in septic shock: a proof of concept randomized, controlled pilot study. J Crit Care. 2019 Feb;49:172-8.

38 Morgera S, Haase M, Kuss T, Vargas-Hein O, Zuckermann-Becker H, Melzer C, et al. Pilot study on the effects of high cutoff hemofiltration on the need for norepinephrine in septic patients with acute renal failure. Crit Care Med. 2006;34(8):2099-104.

39 Geri G, Grimaldi D, Seguin T, Lamhaut L, Marin N, Chiche JD, et al. Hemodynamic efficiency of hemodialysis treatment with high cut-off membrane during the early period of post-resuscitation shock: the HYPERDIA trial. Resuscitation. 2019 Jul;140:170-7.

40 Laurent I, Adrie C, Vinsonneau C, Cariou A, Chiche JD, Ohanessian A, et al. High-volume hemofiltration after out-of-hospital cardiac arrest: a randomized study. J Am Coll Cardiol. 2005;46(3):432-7.

41 Ronco C, Tetta C, Mariano F, Wratten ML, Bonello $\mathrm{M}$, Bordoni $\mathrm{V}$, et al. Interpreting the mechanisms of continuous renal replacement therapy in sepsis: the peak concentration hypothesis. Artif Organs. 2003;27(9):792-801.
42 Bellomo R, Kellum JA, Gandhi CR, Pinsky MR, Ondulik B. The effect of intensive plasma water exchange by hemofiltration on hemodynamics and soluble mediators in canine endotoxemia. Am J Respir Crit Care Med. 2000 May;161(5):1429-36.

43 Ronco C, Ricci Z, Husain-Syed F. From multiple organ support therapy to extracorporeal organ support in critically ill patients. Blood Purif. 2019;48(2):99-105.

44 Ankawi G, Xie Y, Yang B, Xie Y, Xie P, Ronco $\mathrm{C}$. What have we learned about the use of cytosorb adsorption columns? Blood Purif. 2019;48(3):196-202

45 Honore PM, Hoste E, Molnár Z, Jacobs R, Joannes-Boyau O, Malbrain MLNG, et al. Cytokine removal in human septic shock: where are we and where are we going? Ann Intensive Care. 2019 May 14;9(1):56.

46 Ronco C, Reis T, De Rosa S. Coronavirus epidemic and extracorporeal therapies in intensive care: si vis pacem para bellum. Blood $\mathrm{Pu}-$ rif. 2020 Mar 13;49(3):255-8.

47 Fenton MJ, Golenbock DT. LPS-binding proteins and receptors. J Leukoc Biol. 1998 Jul; 64(1):25-32.

48 Opal SM, Scannon PJ, Vincent JL, White M, Carroll SF, Palardy JE, et al. Relationship between plasma levels of lipopolysaccharide (LPS) and LPS-binding protein in patients with severe sepsis and septic shock. J Infect Dis. 1999 Nov; 180(5):1584-9.

49 Rosa S, Villa G, Ronco C. The golden hour of polymyxin $\mathrm{B}$ hemoperfusion in endotoxic shock: the basis for sequential extracorporeal therapy in sepsis. Artif Organs. 2020;44(2): 184-6.

50 De Rosa S, Samoni S, Ronco C. Sequential extracorporeal therapy collaborative device and timely support for endotoxic, septic, and cardiac shock: a case report. Blood Purif. 2019 Dec 19;49(4):502-508.

51 De Rosa S, Villa G, Ronco C. The golden hour of polymyxin B hemoperfusion in endotoxic shock: The basis for sequential extracorporeal therapy in sepsis. Artif Organs. 2020;44(2): 184-6.

52 Honore PM, Jacobs R, Joannes-Boyau O, De Regt J, De Waele E, van Gorp V, et al. Newly designed CRRT membranes for sepsis and SIRS: a pragmatic approach for bedside intensivists summarizing the more recent advances: a systematic structured review. ASAIO J. 2013 Mar-Apr;59(2):99-106.

53 Broman ME, Hansson F, Vincent JL, Bodelsson $M$. Endotoxin and cytokine reducing properties of the oXiris membrane in patients with septic shock: a randomized crossover doubleblind study. PLoS One. 2019;14(8):e0220444.

54 Deye N, Cariou A, Girardie P, Pichon N, Megarbane B, Midez P, et al. Endovascular versus external targeted temperature man- agement for patients with out-of-hospital cardiac arrest: a randomized, controlled study. Circulation. 2015;132(3):182-93.

55 Tissier R, Giraud S, Quellard N, Fernandez B, Lidouren F, Darbera L, et al. Kidney protection by hypothermic total liquid ventilation after cardiac arrest in rabbits. Anesthesiology. 2014;120(4):861-9.

56 Andersson U, Wang H, Palmblad K, Aveberger AC, Bloom O, Erlandsson-Harris $\mathrm{H}$, et al. High mobility group 1 protein (HMG-1) stimulates proinflammatory cytokine synthesis in human monocytes. J Exp Med. 2000 Aug 21;192(4):565-70.

57 Andrassy M, Volz HC, Igwe JC, Funke B, Eichberger SN, Kaya Z, et al. High-mobility group box-1 in ischemia-reperfusion injury of the heart. Circulation. 2008 Jun 24;117(25): 3216-26.

58 Sugita A, Kinoshita K, Sakurai A, Chiba N, Yamaguchi J, Kuwana T, et al. Systemic impact on secondary brain aggravation due to ischemia/reperfusion injury in post-cardiac arrest syndrome: a prospective observational study using high-mobility group box 1 protein. Crit Care. 2017 Sep 26;21(1):247

59 Oda Y, Tsuruta R, Fujita M, Kaneda K, Kawamura Y, Izumi T, et al. Prediction of the neurological outcome with intrathecal high mobility group box 1 and S100B in cardiac arrest victims: a pilot study. Resuscitation. 2012 Aug;83(8):1006-12.

60 Omura T, Kushimoto S, Yamanouchi S, Kudo $\mathrm{D}$, Miyagawa N. High-mobility group box 1 is associated with neurological outcome in patients with post-cardiac arrest syndrome after out-of-hospital cardiac arrest. J Intensive Care. 2016 May 31;4:37.

61 Yumoto M, Nishida O, Moriyama K, Shimomura Y, Nakamura T, Kuriyama N, et al. In vitro evaluation of high mobility group box 1 protein removal with various membranes for continuous hemofiltration. Ther Apher Dial. 2011 Aug;15(4):385-93.

62 Honore PM, De Bels D, Kugener L, Redant S, Attou R, Gallerani A, et al. Validity of the relationship between mobility group box-1 protein and poor post-cardiac arrest neurological outcome during renal replacement therapy. Crit Care. 2019 Mar 12;23(1):84.

63 Schmidt M, Bailey M, Kelly J, Hodgson C, Cooper DJ, Scheinkestel C, et al. Impact of fluid balance on outcome of adult patients treated with extracorporeal membrane oxygenation. Intensive Care Med. 2014 Sep; 40(9):1256-66.

64 Antonucci E, Lamanna I, Fagnoul D, Vincent JL, De Backer D, Silvio Taccone F. The Impact of renal failure and renal replacement therapy on outcome during extracorporeal membrane oxygenation therapy. Artif Organs. 2016 Aug;40(8):746-54.
Blood Purification in the Post-

Resuscitation Syndrome
Blood Purif 2021;50:750-757

DOI: $10.1159 / 000510127$ 